\title{
Nieuwe WA0-plannen goed voor werkgelegenheid verzekeringsartsen
}

\author{
J.J.M. Besseling
}

Het kabinet heeft onlangs vlak na elkaar twee statements gedaan. Met het openbaar maken van de WIA geeft het kabinet aan hoe het de WAO met ingang van 2006 wil hervormen. De stukken zijn dermate omvangrijk dat pas in de loop van de komende maanden alle details zichtbaar zullen worden. Belangrijke wijzigingen zijn in ieder geval het opdelen van de WAO in een regeling voor duurzaam volledig arbeidsongeschikten (IVA) en een regeling voor gedeeltelijk arbeidsongeschikten en voor volledig arbeidsongeschikten bij wie getwijfeld wordt aan de duurzaamheid (WGA). Een andere ingrijpende wijziging is dat deze markt opengesteld wordt voor particuliere verzekeraars. Op deze plannen is door verschillende personen kritiek geleverd. Gewezen is op medicalisering, de prikkels die volledige arbeidsongeschiktheid stimuleren, beroepsziekten waarvan de gevolgen onvoldoende afgedekt worden en de hoge kosten die gemoeid zijn met het openstellen van deze markt voor private verzekeraars waarbij moet blijken of deze meerkosten ooit terugverdiend worden.

Al deze kritiek is in lijn met het tweede statement van het kabinet, namelijk dat de plannen van het kabinet steeds zo cynisch worden ontvangen. Daarom is er in dit redactioneel aandacht voor positieve effecten voor de

\begin{abstract}
beroepsgroep verzekeringsartsen. Aangenomen mag worden dat invoering van de plannen leidt tot extra werkgelegenheid voor verzekeringsartsen. Weliswaar waren voor de eerste claimbeoordeling de afgelopen jaren minder verzekeringsartsen nodig doordat de WAO-instroom drastisch terugliep, maar er gloort weer hoop voor u. Er zal een nieuwe functie bij de particuliere verzekeraars ontstaan, de bvapv (bezwaarverzekeringsarts particuliere verzekeraars). De verzekeraars hebben er straks belang bij om de beslissing van het UWV aan te vechten zodat de kosten niet ten laste komen van de verzekeraar. Vermoedelijk zal getracht worden de kosten af te wentelen op de publiek gefinancierde IVA door volledige arbeidsongeschiktheid te benadrukken of misschien wordt juist de arbeidsgeschiktheid benadrukt en komen de financiële gevolgen voor de werknemer. Het betekent voor de beroepsgroep van verzekeringsartsen extra werkgelegenheid. En dat zal niet ten koste gaan van de werkgelegenheid bij het UWV. Het voornemen is dat $u$, nadat $u$ vastgesteld hebt dat er sprake is van volledige arbeidsongeschiktheid met mogelijk een geringe kans op herstel, elk jaar opnieuw beoordeelt of er sprake is van volledige arbeidsongeschiktheid. Kortom, als verzekeringsarts zit u de komende jaren gebeiteld!
\end{abstract}

\section{INHOUD}

Lezersforum

Onderzoek: Werken in het onderwijs: Literatuuronderzoek $\mathcal{F}$. Konijnenburg

Onderzoek: Prognose van verzuimduur bij psychische aandoeningen E.M. de Croon,

N.I.R. Hugenholtz, K. Nieuwenhuijsen, F.F.H. van Dijk

Column

Opinie: De (re-)integratie van mensen met een handicap in Vlaanderen E. Samoy

Opinie: Oneigenlijk gebruik van de GGZ F.F. van Egmond, M. van de Weerd

Voor de praktij|k: Dilemma voor de verzekeringsarts: De kat op het spek binden

P. Gabeler, W. Koek

Praktijkperikel

Casusbespreking: RSI of bacterie $\mathcal{F}$. Dam

Interview: Cultuuromslag in de aanpak van psychische arboproblematiek vraagt van alle

arbo-actoren verandering; Een interview met Peter van Lieshout, voorzitter subcommissie Psychische Problematiek van de commissie Het Werkend Perspectief, en Bas Sorgdrager, voorzitter NVAB N.H.Th. Croon, A.I.F.Vernooy

Berichten vit het NCvB onder redactie van H.P.F. Stinis 161 